\title{
Cognate objects of weather verbs in African languages of South Africa - from synchronic variation to a grammaticalization path
}

\author{
Alexander Andrason \\ Department of African Languages, Stellenbosch University, South Africa \\ E-mail: andrason@sun.ac.za \\ Marianna W. Visser \\ Department of African Languages, Stellenbosch University, South Africa \\ E-mail: mwv@sun.ac.za
}

\begin{abstract}
The authors argue that the synchronic variation of cognate objects of weather verbs exhibited in six African languages of South Africa (Sepedi, Sesotho, Tshivenda, isiXhosa, Xitsonga, and isiZulu) has a diachronic explanation, and may be represented as a grammaticalization path. This path gradually leads from prototypical cognate objects that disallow object agreement (pronominalization) and promotion to subjects in passive constructions to prototypical objects where both agreement (pronominalization) and promotion are grammatical. This provides further support for the modelling of cognate objects, adjuncts and arguments in terms of a continuum and for a gradient view of syntactic categories, in general.
\end{abstract}

Keywords: African languages; weather verbs; cognate objects; grammaticalization

\section{Background}

Since grammatical "changes are always manifested in synchronic variation" (Andersen 2001: 228), synchronic variation often allows for a diachronic interpretation. Accordingly, variations attested in a language or across languages have commonly been used to postulate tendencies in the development of constructions - the so-called grammaticalization paths (Croft 2003: 232, 272-279). This note deals with the synchronic variation of cognate objects (CO) of weatherverbs attested across six African languages of South Africa (Sepedi, Sesotho, Tshivenda, isiZulu, Xitsonga and isiXhosa), and its reinterpretation in terms of a diachronic development.

From a cross-linguistic perspective, weather verbs typically lack proper participants. They tend to be construed with no reference to external and/or internal arguments, i.e. subject and object. Where such participants are expressed as subjects or objects, these fail to be prototypical. Rather, they draw from the categories of cognate arguments, i.e. elements that are semantically 
indistinguishable from (or similar to) a phenomenon expressed by the (weather) verb itself (Eriksen, Kittilä and Kolehmainen 2010, 2012, 2015).

Across languages, COs exhibit syntactic properties that both relate them to, and distinguish them from genuine objects. In African languages of South Africa, an element is usually classified as a true (or prototypical) object if it conforms to the following criteria: (a) in the canonical word order, it occupies an immediate post-verbal position; (b) it can be pronominalized through object pronominal clitics, or it can be co-indexed on the verb by means of object agreement markers; ${ }^{1}$ (c) it can be promoted to the subject position in passive constructions - it appears in the preverbal subject position and is co-indexed with a subject agreement marker (or a pronominal clitic) on the verb (Du Plessis and Visser 1998: 48-50; Du Plessis 2010). Contrary to genuine objects, typologists view COs as (usually) incompatible with pronominalization and promotion in passive constructions (see Macfarland 1995; Höche 2002; Iwasaki 2007).

\section{Data}

The method adopted in this study consists of testing the COs of weather verbs in the six African languages of South Africa for the three syntactic object diagnostics: position, pronominalization / agreement, and promotion in passives. This will reveal to what extent the analyzed COs are prototypical objects (the three criteria are met) or prototypical COs (only the first criterion is met). ${ }^{2}$

\subsection{Sesotho}

In Sesotho, various weather verbs are complemented by COs - noun phrases that are indistinguishable from the weather phenomenon conveyed by the verb (or subject-verb complex). In the canonical word order, COs immediately follow the predicate, thus occupying the typical object position (Ramathe 1996: 78-82), as illustrated by (1).

$$
\begin{array}{lll}
\text { Pula } \quad \text { e-na } & \text { modupe } & \text { (ibid. 78) } \\
\text { rain SA-rain } & \text { steady.rain }
\end{array}
$$

The pronominalization or the presence of object agreement markers is generally ungrammatical (ibid. 83-85):

\footnotetext{
${ }^{1}$ For a discussion of the status of clitic elements in Nguni as pronominal clitics or agreement markers consult Zeller (2012).

2 The presented evidence draws from the following studies specifically dedicated to weather verbs in the sex African languages of South Africa: Sesotho - Ramathe (1996); Sepedi - Mojapelo (1997); isiXhosa - Andrason and Visser (forthcoming); isiZulu - Mchunu (1996); Tshivenda - Nekhumbe (1995); Xitsonga - Mdumela (1996) and Du Plessis (2016). With the distinction of isiXhosa and, partly, isiZulu, the presented data is secondary.

${ }^{3}$ Other examples of weather verbs occurring with COs are tlopoletsa 'rain heavily', rotha 'drop', phukgama 'fall heavily', kgetheha 'snow', foka 'blow', puka 'blow hard', kirietsa 'thunder', thwathwaratsa 'thunder', and duma 'roar'. Further examples of possible COs are matlopotlopo 'thick shower', motloporo 'strong rain', marothodi 'drops', and kgetheho 'fall of snow', lefokafoka 'wind', lepukupuku 'wind with dust', kirietsa 'thunder', medumo 'roars', lethwathwarathwara 'thunder', and majwana 'hailstones' (Ramathe 1996: 78-80).
} 


$$
\begin{aligned}
& \text { Pula } \quad \text {-*a-na } \quad \begin{array}{l}
\text { matlopotlopo (ibid. 83) } \\
\text { rain SA-OA-rain } \\
\text { shower.rain }
\end{array} \\
& \text { Intended meaning: "Rain rains (it) a thick shower rain." }
\end{aligned}
$$

In passive constructions, cognate objects of the weather verbs cannot be promoted to the subject position (ibid. 86-88). For example, in (3), the noun phrase modupe 'steady rain' cannot occupy the subject position and trigger subject agreement on the passive form of the verb na 'rain'.

$$
\begin{aligned}
& \text { *Modupe } \quad o-a-n e-w a \text { (ibid. 86) } \\
& \text { rain } \quad \text { SA-PRES-rain-PASS } \\
& \text { Intended meaning: "A steady rain is fallen." }
\end{aligned}
$$

\subsection{Sepedi}

COs constitute a common feature of weather verbs in Sepedi (Mojapelo 1997: 79-80; Du Plessis 2010: 18). A representative case is provided in (4) where the nominal element mono 'rain' pleonastically complements the verb $n a$ 'rain'. In the canonical word order, COs occupy a postverbal position typical of objects.

$$
\begin{aligned}
& \text { Pula } \quad \text { e-na } \quad \text { mono }^{4} \text { (Mojapelo 1997: 79) } \\
& \text { rain SA-rain rain } \\
& \text { "Rain rains the raining." }
\end{aligned}
$$

Although the use of object agreement markers or pronominal clitics is usually ungrammatical (5.a), in a few exceptional cases, agreement/pronominalization is acceptable (Mojapelo 1997:

\begin{tabular}{|c|c|c|c|}
\hline $\begin{array}{l}\text { *Morotho } \\
\text { dripping }\end{array}$ & $\begin{array}{l}o \text {-roth-wa } \\
\text { SA-drip-PASS }\end{array}$ & $\begin{array}{l}k e \\
\text { by }\end{array}$ & pula (Du Plessis 2010: 20) \\
\hline
\end{tabular}
81-82; Du Plessis 2010). For examples, in (5.b), the element pula 'rain' is co-indexed with the object agreement marker $a$ found in the verbal complex. ${ }^{5}$

$$
\begin{aligned}
& \text { a. } \quad \text { Morotho }_{i} \quad \text { ya-o } \text {-rotha }_{\text {-rota }} \text { puld Pussis 2010: 19) } \\
& \text { dripping SA-OA-drip rain } \\
& \text { Intended meaning: "The dripping, rain dripped it / Rain dripped the dripping." } \\
& \text { b. } \quad \text { Marothi }_{i} \quad \text { ya-a-rotha pula (Mojapelo 1997: 81) } \\
& \text { drops SA-OA-drip rain } \\
& \text { "Drops, rain dripped them / Rain dripped the drops." }
\end{aligned}
$$

In most instances, COs of weather verbs cannot be promoted to the subject position in passive constructions (6.a). However, with a few verbs (namely rotha 'drip' and duma 'thunder') and CO (e.g. marothi 'drops' and modumo 'thunder'), ${ }^{6}$ the promotion is possible (6.b) (ibid. 82):

\footnotetext{
${ }^{4}$ Similar constructions are found with verbs such as rotha 'drip', wa 'fall', duma 'thunder', rothotha 'rain heavily', and gadima 'flash', and nouns such as morotho 'dripping', marothi 'drops', morothotho 'heavy fall' mowo 'a (snow) fall', and mogadimo 'flashes' (Mojapelo 1997: 79-80).

${ }^{5}$ The other combination that tolerates object agreement or pronominalization is duma 'to thunder' + modumo 'the thunder' (Mojapelo 1997: 81-82).

${ }^{6}$ Note that these are the same verbs that allow for object agreement and pronominalization.
} 


\begin{tabular}{|c|c|c|c|}
\hline $\begin{array}{l}\text { Marothi } \\
\text { drops }\end{array}$ & $\begin{array}{l}a \text {-roth-wa } \\
\text { SA-drip-PASS }\end{array}$ & $\begin{array}{l}\text { ke } \\
\text { by }\end{array}$ & $\begin{array}{l}\text { pula (Mojapelo 1997: 82) } \\
\text { rain }\end{array}$ \\
\hline
\end{tabular}

\subsection{IsiXhosa}

The use of COs is a common feature of the majority of weather verbs in isiXhosa (7) (Andrason and Visser forthcoming). In such instances, the CO (e.g. isiphango 'storm') tends to occupy an immediate postverbal position, typical of objects:

$$
\begin{array}{lll}
\text { Imvula } & \text { i-netha } & \text { isiphango } \\
\text { rain } & \text { SA-rain } & \text { rain.storm } \\
\text { "It is storming (lit. Rain rains a rain storm)." }
\end{array}
$$

All such COs may usually be indexed on the verb by means of pronominal clitics or object

\begin{tabular}{|c|c|c|c|}
\hline a. & $\begin{array}{l}\text { Imvula } \\
\text { rain }\end{array}$ & $\begin{array}{l}i-y a w u_{i}-n a \\
\text { SA-OA-rain }\end{array}$ & $\begin{array}{l}\text { umkhwitsho } \\
\text { drizzle }\end{array}$ \\
\hline & "The ra & s a drizzle." & \\
\hline b. & $\begin{array}{l}\text { Imvula } \\
\text { rain }\end{array}$ & $\begin{array}{l}i \text {-yasi }{ }_{-} \text {-netha } \\
\text { SA-OA-rain }\end{array}$ & $\begin{array}{l}\text { isiphango }_{i} \\
\text { rain.storm }\end{array}$ \\
\hline
\end{tabular}
agreement markers (ibid.):

The weather constructions containing COs cannot be passivized (19.a-b). Accordingly, the CO of an active weather verb cannot be promoted to the subject of a corresponding passive construction nor can the active subject be expressed by a postverbal copulative phrase (ibid.):
a. *Umkhwitsho u-ya-n-iwa
(yi-mvula)
drizzle SA-PRES-rain-PASS
(by-rain)
Intended meaning: "The drizzle is rained (by rain)."
b. *Isiphango si-ya-gxigxis-wa (yi-mvula)
rain.strorm SA-PRES-rain.heavily-PASS (by-rain)
Intended meaning: "The rain storm is rained (by rain)."

\section{$2.4 \quad$ IsiZulu}

COs are widely tolerated by weather verbs in isiZulu (Mchunu 1996: 52). For instance, in (10), the verb khiza 'drizzle' is redundantly accompanied by the noun umkhizo that refers to the same weather phenomenon, i.e. 'drizzle'. In the canonical word order, such COs occur in the object position, thus following the verb:

\footnotetext{
${ }^{7} \mathrm{CO}$ constructions may also be formed with objects such as umkhwitsho, intshazane and umtshizo 'drizzle', izandyondyo, umvu/imbi and isiphango 'heavy rain', isichotho 'hail' and iliqhwa 'sleet'; and verbs such as -na and -netha 'rain', khwitsha 'drizzle', dyudyuza, ngxaza ngxaza, gxagxaza, and gxigxiza 'rain heavily', and wa 'fall, precipitate' (Andrason and Visser forthcoming).
} 


$\begin{array}{lll}\text { Imvula } & \text { i-khiza } & \text { umkhizo }{ }^{8} \text { (ibid. 48) } \\ \text { rain } & \text { SA-drizzle } & \text { drizzle } \\ \text { "Rain drizzles drizzle." } & \end{array}$

Object agreement (or pronominalization) is grammatical in these types of $\mathrm{CO}$ constructions as illustrated by (11) (Mchunu 1996: 48, 52; see also Hlongwane 1976: 59):

$$
\begin{aligned}
& \text { Imvula } \quad \begin{array}{l}
\text {-yawu } \\
\text { rain }
\end{array} \quad \text { SA-OA-rain convimbi } \\
& \text { "The rain rains (it) continuous rain." }
\end{aligned}
$$

COs may also be moved to the subject position in passive constructions (Mchunu 1996: 53). However, the passives formed with weather verbs are not accompanied by the copulative phrase that expresses the agent (Mchunu 1996: 52; cf. Hlongwane 1976: 54-56), regularly acceptable in other types of passive constructions (Zievogel, Louw and Taljaard 1976: 108; Poulos and Msimang 1998: 191-193, 371). In such instances, the demoted subject of an active weather verb appears directly after the verb, being only marked by tone, not by the copulative.

$\begin{array}{lll}\text { Amaconsi } & \text { a-cons-wa } & \text { imvula }(\text { Mchunu 1996: 52) } \\ \text { drops } & \text { SA-drip-PASS } & \text { rain } \\ \text { "Drops are dripped by rain." } & \end{array}$

\subsection{Tshivenda}

Weather verbs may also appear with COs in Tshivenda (Nekhumbe 1995: 47-50). In the canonical word order, they occupy a postverbal, object position as demonstrated by vhusuto 'drizzle' (pleonastic complement of suta 'drizzle') below:

$\begin{array}{lll}\begin{array}{lll}\text { Mvula } & \text { i-suta } & \text { vhusuto } \\ \text { rain } & \text { SA-drizzle } & \text { drizzle }\end{array} \\ \text { "Rain drizzles drizzle." } & \end{array}$

In these types of constructions, COs may be pronominalized or co-indexed with object agreement markers (Nekhumbe 1995: 51; Du Plessis 2010). In (14), the CO marotha 'drops' is co-indexed with the object agreement marker $a-a$ of the corresponding noun class (i.e. class 6 ).

$$
\begin{aligned}
& \text { Mvula } i \text {-aa } a_{i} \text {-rotha } \text { marotha }_{i} \text { (Nekhumbe 1995: 51) } \\
& \text { rain SA-OA-drip drops } \\
& \text { "Rain drips (them) drops." }
\end{aligned}
$$

$\mathrm{CO}$ constructions may also be passivized with the $\mathrm{CO}$ being promoted to the subject position (Nekhumbe 1995: 51-52; Du Plessis 2010). In such cases, the verb exhibits a subject agreement marker that is co-indexed with the promoted CO - compare a-rothwa (class 6) and marotha (class 6) in the example below:

\footnotetext{
${ }^{8}$ This construction type is also possible with verbs like na 'rain', consa 'drip', and phazima 'flash' and nouns such as umvimbi 'continuous rain', amaconsi 'drops', and umbani 'lightning' (Mchunu 1996: 48, 51-52).

${ }^{9}$ This construction is also admissible with other verbs (e.g. rotha 'drip', bvuma 'thunder', penya 'flash') and nouns (e.g. marotha 'drops', mubvumo 'thunder', and phenyo 'lightning') (Nekhumbe 1995: 47, 50).
} 


$\begin{array}{llll}\text { Marotha } & \text { a-roth-wa } & \text { nga } & \text { mvula (Nekhumbe 1995: 51) } \\ \text { drops } & \text { SA-drip-PASS } & \text { by } & \text { rain }\end{array}$

\subsection{Xitsonga}

Xitsonga attests to a variety of CO constructions with weather verbs (Mdumela 1996: 71-72: Du Plessis 1999: 222-225, 2010, 2016). In the canonical type of word order, COs appear in a postverbal object position, as illustrated by ndhambi 'heavy rain' in the following example:

\begin{tabular}{|c|c|c|}
\hline $\begin{array}{l}\text { Mpfula } \\
\text { rain }\end{array}$ & $\begin{array}{l}y i-n a \\
\text { SA-rain }\end{array}$ & $\begin{array}{l}\text { ndhambi }{ }^{10} \text { (Mdumela 1996: 72) } \\
\text { heavy.rain }\end{array}$ \\
\hline
\end{tabular}

CO constructions generally tolerate pronominal clitics and object agreement (Mdumela 1996: 73-75; Du Plessis 2016: 12-13). Accordingly, COs can be pronominalized (17.a) or co-indexed with object agreement markers (17.b-c).

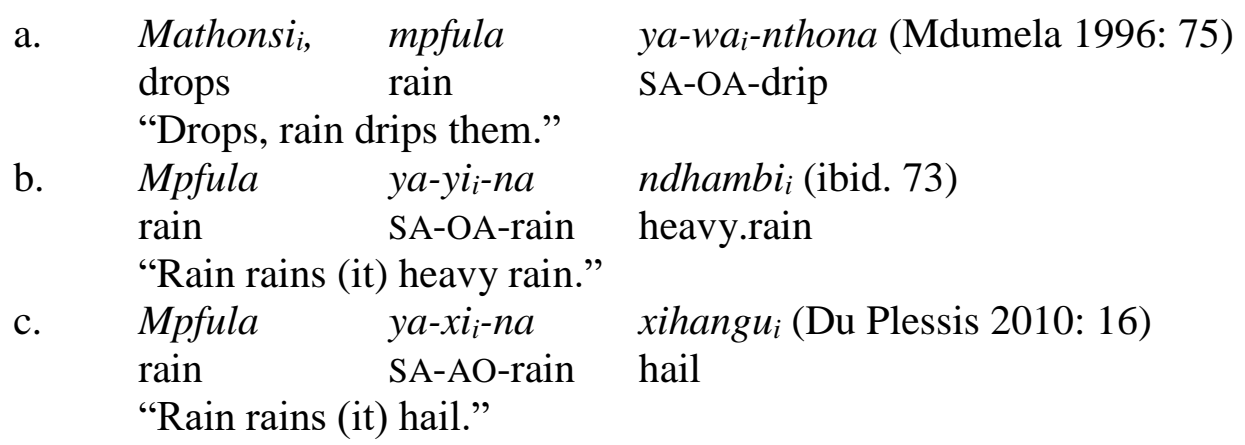

Similarly, the passivization of the weather-verb $\mathrm{CO}$ constructions is grammatical. The $\mathrm{CO}$ can be moved to the empty subject slot (see ndhambi 'heavy rain' and mathonsi 'drops' in 18.a and 18.b respectively), triggering subject agreement on the verb (Mdumela 1996: 76-77; Du Plessis 2010: 17, 2016: 12, 14):
a. Ndhambi yi-n-iwa hi heavy.rain SA-rain-PASS by "Heavy rain is rained by rain."
b. Mathonsi ya-nthon-iwa hi mpfula (ibid.) drops SA-rain-PASS by rain "Drops are dropped by rain."

\section{Discussion - from linguistic variation to a grammaticalization path}

The six African languages of South Africa discussed in this study attest to a considerable variation in the treatment of COs of weather verbs. In some languages, COs exhibit certain syntactic properties typical of genuine objects. In other languages, however, their syntactic

\footnotetext{
${ }^{10}$ These types of constructions are also possible with other verbs (e.g. nthona 'drip', hunga 'blow', hatima 'flash') and nouns (e.g. mathonsi 'drops', rihati 'lightning', ximbhembhe 'storm wind', bubutsa 'dust storm', xihuhuri 'whirlwind', xihangu 'hail', and mirubi ‘continuous rain') (Mdumela 1996: 72; Du Plessis 2010).
} 
behavior fully conforms to genuine objects. Inversely, in some languages, COs are prototypical instantiations of the $\mathrm{CO}$ category, while in others their compliance with the $\mathrm{CO}$ prototype is low. The prototypicality of being a true internal argument (object) is inversely proportional to the prototypicality of being a CO. As the former increases, the latter decreases.

In Sesotho, COs of weather verbs fail to be genuine objects - their pronominalization (or use with object agreement markers) and promotion to subjects in passive constructions is ungrammatical (Ramathe 1996: 85, 88). In Sepedi, the ungrammaticality of object agreement with COs (or pronominalization) and their promotion in passives is less uniform. Although most COs cannot be marked on the verb by means of object agreement markers and pronominal clitics, nor can they be promoted to subjects in passive constructions, a few exceptions to both tendencies are found (Mojapelo 1997: 82). In isiXhosa, COs of weather verbs can regularly be indexed on the verb by means of object agreement affixes or pronominal clitics. However, contrary to constructions involving exemplary objects, weather verbs containing COs cannot be passivized. Accordingly, such COs are viewed as semi-prototypical - an intermediate stage between a prototypical CO and a prototypical object (Andrason and Visser forthcoming). In isiZulu, the COs of weather verbs are nearly true arguments. They can be pronominalized and promoted to subjects in passives, although the latter disallows the use of copulative agentive phrases (Mchunu 1996: 53). In Tshivenda (Nekhumbe 1995: 47, 52) and Xitsonga (Mdumela 1996: 73, 75-77; Du Plessis 1999: 222-225; Du Plessis 2010) the co-indexation of COs by means of object agreement markers, their pronominalization with clitics, and promotion to subjects in passive constructions (also with copulative agent-like complements) are fully grammatical - COs behave as prototypical objects. All the evidence is summarized in the following table:

Table 1: Object properties of COs of weather verbs in the African languages of South Africa

\begin{tabular}{|l|c|c|c|}
\hline & Object position & Object agreement (pronom.) & Promotion \\
\hline Sesotho & + & - & - \\
\hline Sepedi & + & $-/(+)$ & $-/(+)$ \\
\hline isiXhosa & + & + & - \\
\hline isiZulu & + & + & + (no copulative) \\
\hline Tshivenda & + & + & + \\
\hline Xitsonga & + & + & + \\
\hline
\end{tabular}

We propose that the variation attested in the six African languages reveals a grammaticalization path. The prototype of a CO used with weather verbs fails to tolerate object agreement or pronominalization, and promotion to the subject position (stage 1). The only syntactic property which it shares with genuine objects is the postverbal position in the canonical word order (Sesotho). At a subsequent stage (stage 2), COs may be pronominalized or co-indexed with agreement markers (isiXhosa). However, their passivization is ungrammatical. Lastly, at the final stage (stage 3), COs may be promoted to the subject role in passive constructions apart from being pronominalized and accompanied by object agreement markers (Tshivenda and Xitsonga). At the end of the process, COs are genuine objects and weather verbs are true accusative verbs (Figure 1). As is typical of grammaticalization, the process is gradual with intermediate transition phases between the distinguished stages. Sepedi arguably attests to the transition between stage 1 and stage 2, while isiZulu attests to the transition between stage 2 
and stage 3. The cline is possibly universal suggesting that pronominalization regularly precedes passivization in the adaptation of COs to genuine objects.

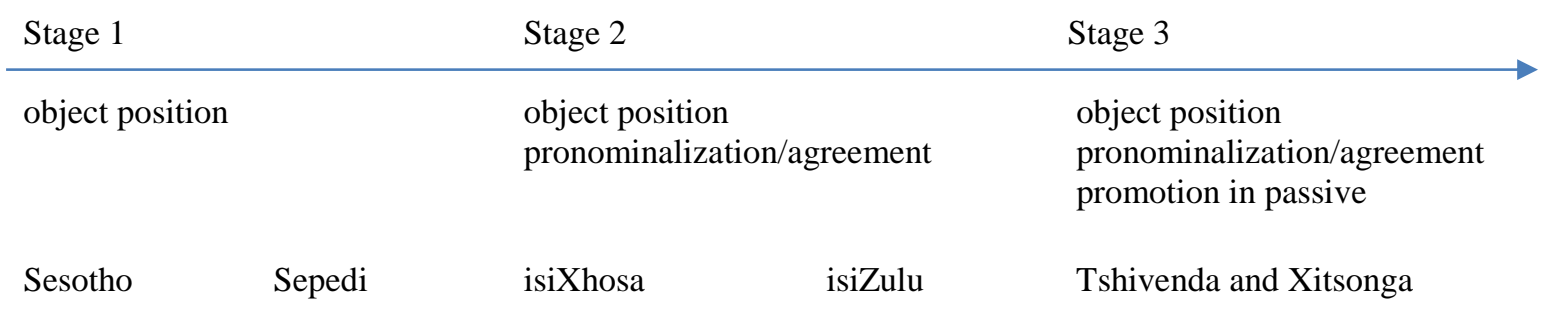

Figure 1: Grammaticalization path of COs of weather verbs ${ }^{11}$

Our results corroborate the understanding of cognate object constructions in terms of a sequence of stages that link prototypical intransitivity and prototypical transitivity, as postulated by Höche (2002: 168-169). According to that view, CO constructions deliver a set of variants from those that are more intransitive-like (unaccusative and unergative) to fully transitive $\mathrm{CO}$ constructions (ibid.). In the former variants, COs exhibit exemplary $\mathrm{CO}$ properties, while in the latter variants, they behave like (or similarly to) genuine objects.

From a broader perspective, this research provides further support for syntactic gradience (Aarts 2007; Traugott and Trousdale 2010). Specifically, it corroborates a fuzzy transition from the category of adjunct to that of (internal) argument, through a cloud of less prototypical objects (Aarts 2007: 174-175, 186; Andrason forthcoming). Prototypical COs would constitute a class of such non-prototypical objects - the so-called objoid (Allerton 2006: 164). Less prototypical COs would, however, gradually approach the category of object. Therefore, it is not only the adjunct-argument split that is gradient. The intersective (i.e. semi-adjunct and semi-object) category of COs is gradient as well.

\title{
4. Conclusion
}

The present note demonstrates that the variation in properties of COs of weather verbs attested synchronically in six African languages of South Africa may have a diachronic explanation in terms of a grammaticalization path. This path leads from prototypical COs that disallow object agreement / pronominalization and promotion in passives to prototypical objects where both agreement / pronominalization and promotion are allowed. This supports the understanding of COs as gradient, the same for adjunct-argument distinction, and syntactic categories in general.

\begin{abstract}
Abbreviations
$\mathrm{CO}$ - cognate object; OA - object agreement / pronominal clitic; SA - subject agreement; PASS - passive; PRES - present.
\end{abstract}

\section{References}

Aarts, B. 2007. Syntactic gradience. Oxford: Oxford University Press.

\footnotetext{
${ }^{11}$ The position of specific languages on this continuum is, of course, approximate.
} 
Allerton, D. 2006. Verbs and their satellites. In B. Aarts and A. McMahon (eds.) The handbook of English linguistics. Malden: Blackwell. pp. 146-179.

Andersen, H. 2001. Actualization and the (uni)directionality. In H. Andersen (ed.) Actualization: Linguistic change in progress. Amsterdam: John Benjamins. pp. 225-248.

Andrason, A. forthcoming. The Argument-Adjunct Scale: Applied Nominal and Locative Phrases in Xhosa. Linguistic Discovery 15.

Andrason, A. and M. W. Visser. forthcoming. Precipitation constructions in isiXhosa.

Croft, W. 2003. Typology and universals. Cambridge: Cambridge University Press.

Du Plessis, J. A. 1999. Lexical semantic and the African languages. Stellenbosch Communications in African Languages 8. Stellenbosch: Stellenbosch University.

Du Plessis, J. A. 2010. Comparative syntax: The structure of the verb phrase in the African languages of South Africa (Bantu languages). Stellenbosch: Stellenbosch University. http://scholar.sun.ac.za/handle/10019.1/3156

Du Plessis, J. A. 2016. The verb in Xitsonga. Stellenbosch: Stellenbosch University. http://scholar.sun.ac.za/handle/10019.1/99878

Du Plessis, J. A. and M. W. Visser. 1998. Isintaksi yesixhosa. Stellenbosch Communications in African languages 7. Stellenbosch: Stellenbosch University.

Eriksen, P., S. Kittilä and L. Kolehmainen. 2010. The linguistics of weather: Cross-linguistic patterns of meteorological expressions. Studies in Language 34: 565-601.

Eriksen, P., S. Kittilä and L. Kolehmainen. 2012. Weather and language. Language and Linguistics Compass 6: 383-402.

Eriksen, P., S. Kittilä and L. Kolehmainen. 2015. The world is raining. Meteorological predicates and their subjects in a typological perspective. In M. L. Helasvuo and T. Huumo (eds.) Subjects in Constructions - Canonical and Non-canonical. Amsterdam: John Benjamins. pp. 205-228.

Hlongwane, J. B. 1976. A study of a predicate in its relationship to the subject, object and adjunct in Zulu. MA dissertation, University of South Africa.

Höche, S. 2009. Cognate object constructions in English. A cognitive-linguistic account. Tübingen: Narr.

Iwasaki, S. 2007. A cognitive analysis of English cognate objects. Constructions 1: 1-40.

Macfarland, T. 1995. Cognate objects and the argument/adjunct distinction in English. $\mathrm{PhD}$ dissertation, Northwestern University, Evanston. 
Mchunu, S. 1996. Weather verbs in IsiZulu. MA dissertation, Stellenbosch University.

Mdumela, T. 1996. Weather verbs in Tsonga. MA dissertation, Stellenbosch University.

Mojapelo, M. 1997. Weather verb constructions in Northern Sotho. MA dissertation, Stellenbosch University.

Nekhumbe, M. 1995. Weather verbs in Venda. MA dissertation, Stellenbosch University.

Poulos, C. and C. Msimang. 1998. A Linguistic Analysis of Zulu. Cape Town: Via Afrika.

Ramathe, P. 1996. Weather verbs in Sesotho. MA dissertation, Stellenbosch University.

Traugott, E. C. and G. Trousdale. 2010. Gradience, gradualness and grammaticalization. How do they intersect? In E. C. Traugott and G. Trousdale (eds.) Gradience, gradualness and grammaticalization. Amsterdam: John Benjamins. pp. 19-44.

Zeller, J. 2012. Object marking in isiZulu. Southern African Linguistics and Applied Language Studies 30(2): 219-235.

Ziervogel, D., J. A. Louw and P. C. Taljaard. 1976. A handbook of the Zulu language. Pretoria: Van Schaik. 